Analyses of chalk fragments from Plot 5 (0.5-2 mm. diameter, isolated from $100 \mathrm{gm}$. soil sampled in 1865 and from $500 \mathrm{gm}$. from later samples) showed that the phosphate and fluorine contents increased gradually with time, and at an increased rate from about 1888 onwards. From 1852 until 1888 the superphosphate had been made from bone ash, which contains little fluorine; afterwards mineral phosphate was used and considerable amounts of fluorine would therefore be added annually.

$\mathrm{P}_{2} \mathrm{O}_{3}$ AND $\mathrm{F}$ PERCENTAGES IN CHALK FRAGMENTS FROM BROADBALK

$\begin{array}{ll} & \\ \text { Plot } 5 & \\ & 1865 \\ & 1881 \\ & 1893 \\ & 1901 \\ & 1914 \\ \text { Plot } 3 & 1944 \text { (section 4) } \\ & 1881 \text { (section 4) } \\ & 1944 \text { (section }\end{array}$

$\% \mathrm{P}_{\mathrm{s}} \mathrm{O}_{3}$
$0 \cdot 28$
$0 \cdot 44$
$0 \cdot 80$
$1 \cdot 15$
$1 \cdot 7$
$2 \cdot 8$
$0 \cdot 13$
$0 \cdot 33$

$\% \mathrm{~F}$ n.d. 0.032 0.045 0.078 $0 \cdot 11$ 0.25 0.032
n.d.

Throughout the experiment the plots have steadily lost calcium carbonate by leaching ${ }^{2}$. This may account in part for the increase in $\mathrm{P}_{2} \mathrm{O}_{6}$ percentage in the chalk fraction of the unmanured plot, but it can only be a secondary factor in the accumulation of phosphate in the chalk from Plot 5.

Further work is in progress on the formation of apatite in soils and its relation to phosphate fixation.

\section{G. NAGELSCHMIDT.}

H. L. NIXoN.

Chemistry Department,

Rothamsted Experimental Station,

Harpenden, Herts.

${ }^{1}$ MacIntire, W. H., and Hatcher, B. W., Soil Science, 63, 43 (1942) 'Hall, A. D., and Miller, N. H. J., Proc. Roy. Soc., B, 77. 1 (1905).

\section{Heredity, Development and Infection}

DR. DARtINGTON's ${ }^{1}$ interesting article on "Heredity, Development and Infection" calls for two comments. He states that the "molecular system" of heredity, consisting of plasmagenes, "has been hitherto supposed to be purely maternal in inheritance". There is at least one case to the contrary in animal genetics. L'Héritier and Teissier ${ }^{2}$ found that the character of susceptibility to carbon dioxide in Drosophila melanogaster was transmitted to all the progeny of a susceptible mother, but to a fraction only of those of a susceptible father. Kalmus ${ }^{3}$ found that the same was true in an interspecific cross.

Dr. Darlington later cites Crane and Lawrence's" conclusion that roses may revert from the climber to the bush type as the result of bud-grafting on to a dwarf stock. He regards the agent transmitted as a plasmagene rather than a virus, since the bushy habit of growth in roses cannot be considered pathological. He later adds that "The high frequency of plasmagene and virus mutations, aggravated by the rapidity of their selection, both under nuclear control, gives an almost Lamarckian colour to their adaptation".

Lysenko and his colleagues in the U.S.S.R. have reported a large number of cases in which characters have been transmitted from one plant variety to another by grafting. They have been accused of Lamarckism, among other things. It would seem that British plant geneticists are now discovering similar phenomena. It may be that Lysenko, with the enthusiasm of a pioneer, has criticized Mendelian conceptions unjustifiably, as the biometric school did in Great Britain. But this is scarcely a sufficient reason for ignoring his work, particularly as some of his publications antedate that cited by Dr. Darlington. I yield to no one in my admiration of the work of the American drosophilists on nuclear genetics, which I supported in Great Britain when the chromosomal theory of inheritance was unfashionable. But perhaps we can also learn from our other allies.

Department of Biometry, J. B. S. HALDANE.

University College, London, at Rothamsted Experimental Station, Harpenden. Aug. 25.

1 Nature, 154, 164 (1944).

C.R. Acad. Sci. Paris, 205, 1099 (1937); 206, 1193, 1683 (1938). Nature, 152, 692 (1943).

"Genetics of Garden Plants", 2nd ed. (London, 1937).

\section{Pressor Effects of Amidine Derivatives}

MANY compounds of general formula $R . X . \mathrm{C}(: \mathrm{NH}) \mathrm{NH}_{2}-$ where $R$ is an alkyl group attached to the amidine portion of the molecule either directly ('amidines') or through a divalent radical, $X$, which may be an oxygen atom (iso-ureas), a sulphur atom (iso-thioureas) or an imino-group (guanidines)--have in common a number of distinctive pharmacological properties ${ }^{1-4}$. Thus representative members of each series have been shown to raise the blood pressure of anæsthetized animals and to enhance the pressor effect of adrenaline by mechanisms which are either partly or wholly peripheral. The increase in tonus produced in different smooth muscle preparations is probably the result of a direct action on the muscle itself $2,3,4$.

These investigations have since been extended. Preliminary tests were carried out with some two hundred compounds, the following effects, which were recorded as in previous studies, being looked for particularly as criteria of activity : elevation of the blood pressure in dogs and cats anæsthetized with sodium barbitone, inereased pulmonary ventilation and an enhanced response to adrenaline. The evidence obtained strongly suggests that, whereas such activity is fairly widely distributed among amidine deriva. tives, it is inconspicuous, if present at all, in most related substances. Thus it was not apparent in imino-ethers or in ureas, thioureas, thiohydantoins, carbamates, thiocarbamates and similar compounds which have an amide or thioamide but not the struc. turally similar amidine group.

In the iso-thiourea series, where the relationship between structure and activity was studied especially, it was found that a variety of substituents could be introduced into the molecule without pressor activity necessarily being lost, salts of (2-methyl-)allyl isothiourea, (3-hydroxy-)n-propyl iso-thiourea, methoxymethyl iso-thiourea (I), (2-phenyl-)ethyl iso. thiourea, ethylenej iso-thiourea (II), methyl N, N'. diphenyl iso-thiourea (III), and numerous similar derivatives all raising the blood pressure in doses of 1-10 mgm. $/ \mathrm{kgm}$. Pressor activity was most evident in the lower homologues of methyl iso-thiourea but, unlike methylene di-iso-thiourea (IV), formamidine disulphide (V) had little effect on the blood pressure. A few related compounds (for example, hexamethylene 